\title{
Hubungan Antara Pembelajaran Konsep Dasar Keperawatan Dalam Perkuliahan Dengan Pengaplikasian Proses keperawatan di Rumah Sakit
}

\author{
Cut Tari
}

e-Mail cuttari19@gmail.com

\begin{abstract}
Abstrak
Latar belakang: Sebagai mahasiswa jurusan keperawatan tentunya para mahasiswa harus mempelajari pelajaran yang berkaitan dengan keperawatan salah satu mata kuliah adalah konsep dasar keperawatan dimana salah satu topiknya adalah proses keperawatan ,maka dari itu sangat penting bagi mahasiswa untuk memahami dengan baik tentang proses keperawawatan supaya pada saat bekerja dirumah sakit dapat mengaplikasikannya dengan baik ,sehingga perawat tersebut dapat meberikan pelayanan kepada klien,keluarga,maupun masyarakat dengan profesional.Tujuan:untuk menganalisa serta mengetahui hubungan antara mempelajari konsep dasar keperawatan dengan pengaplikasian di rumah sakit. Metode: Metode yang digunakan oleh penulis adalah Literature review dimana dilakukan dengan cara menganalisis kajian ,eksplorasi jurnal, maupun e-book Adapun jurnal yang digunakan pada literature review ini adalah jurnal yang diterbitkan dari kurun waktu 10 tahun terakhir yang didapatkan dengan menggunakan dua database Portal Garuda dan Google Scholar dan referensi yang digunakan sebanyak 14. Kesimpulan:antara pembelajaran konsep dasar keperawatan di perkuliahan dengan pengaplikasian proses keperawatan di rumah sakit memiliki hubungan yaitu semakin seorang mahasiswa paham dengan apa yang dipelajarinya pada saat di bangku kuliah akan membuat seorang mahasiswa tersebut menjadi lebih baik dalam pengaplikasiannya pada saat di rumah sakit.
\end{abstract}

Kata Kunci: Konsep Dasar Keprawatan,Proses Keperawatan,Rumah Sakit

\begin{abstract}
Background: As students majoring in nursing of course students must learn subjects related to nursing one of the subjects is the basic concept of nursing where one of the topics is the nursing process, therefore it is very important for students to understand well about the nursing process so that when work in a hospital can apply it well, so that the nurse can provide services to clients, families, and the community with a professional. Purpose: to analyze and find out the relationship between learning the basic concepts of nursing with hospital applications.

Methods: The method used by the author is Literature review which is done by analyzing studies, exploration of journals, and e-books. The journals used in this literature review are journals published from the last 10 years that were obtained using two Garuda Portal databases. and Google Scholar and references are used as many as 14. Conclusion: between learning the basic concepts of nursing in lectures with the application of the nursing process in hospitals has a relationship that is more a student understands what he learns while in college will make a student better in its application at the hospital.
\end{abstract}

Keywords: Basic Concepts of Nursing, Nursing Process, Hospital 


\section{PENDAHULUAN}

\section{Latar Belakang}

Sebagai mahasiswa jurusan keperawatan tentunya para mahasiswa di tuntut untuk mempelajari pelajaran yang berkaitan dengan keperawatan salah satu mata kuliah yang berkaitan dengan keperawatan dan mempelajari tentang keperawatan adalah konsep dasar keperawatan.

Untuk menjadi seorang perawat tentu saja mahasiswa keperawatan dituntut untuk memiliki kemampuan dalam pengambilan keputusan yang teeliti serta benar juga didukung oleh kemampuan dalam memahami konsep-konsep yang terkait dengan pelayanan keperawatan yang nantinya akan diterapkan oleh mahasiswa keperawatan ketika sudah bekerja dan menjadi profesi keperawatan .

Potter, P.A. dan Perry, A.G. (1999) mengatakan bahwa seorang perawat memiliki tanggung jawab ketika mengambil keputusan klinis karena keputusan tersebut haruslah akurat dan sesuai. Dalam membantu pasien untuk memelihara, memperoleh dan meningkatkan kesehatannya, seorang perawat harus mampu berfikir kritis dalam menyelesaikan masalah serta mencari solusi bagi masalah tersebut dengan baik. Ketika Mahasiswa keperawatan sudah bekerja pastinya mereka akan menemui berbagai reaksi pasien tergantung dari mana pasien berasal, pengalaman yang diperoleh sebelumnya, ataupun kondisi sakit yang diderita oleh pasien tersebut.

Untuk itu sangat erat kaitannya antara pembelajaran konsep dasar keperawatan dengan pengaplikasian proses keperawatan di rumah sakit,karena dengan belajarnya mahasiswa mengenai mata kuliah konsep dasar keperawatan membuat mahasiswa menjadi tahu tentang teori proses keperawatan yang nantinya proses keperawatan yang berupa terori tersebut yang dipelajari mahasiswa ketika di bangku kuliah dapat di aplikasikan oleh mereka mahasiswa yang akan menjadi perawat mengenai proses keperawatan.

$$
\text { Pendidikan merupakan suatu }
$$
proses yang begitu kompleks dengan tujuan akhir di harapkan terjadi perubahan perilaku pada diri seseorang, dalam pendidikan keperawatan membutuhkan proses belajar yang dapat merubah perilaku dalam dunia pendidikan keperawatan, sebagaimana hakekatnya pendidikan keperawatan adalah bagian dari pendidikan nasional yang mana pola pendidikannya tersebut terdiri dari dua 
aspek yakni yang pertama yaitu pendidikan akademik dan yang kedua adalah pendidikan pofesi. Mahasiswa yang menempuh pendidikan keperawatan pada tahap akademik para mahasiswa tersebut akan mendapatkan teori dan konsep. Mahasiswa yang menempuh pendidikan keperawatan pada tahap profesi mereka akan mengaplikasikan teori dan konsep yang telah didapat selama tahap akademik,salah satu teori dan konsep yang akan merekea aplikasian ketika profesi adalah mata kuliah konsep dasar keperawatan dimana salah satu topik yang dibahas adalah mengenai proses keperawatan dan proses berpikir krtis yang keduanya sangat besar dampak nya ketika mahasiswa keprawatan yang sedang melakukan profesi mengaplikasikannya.

Mahasiswa selama menjalankan pendidikan akademik akan mendapatkan teori dan konsep ilmu serta pengalaman mengenai profesi keperawatan.Teori dan konsep ilmu serta pengalaman belajar mengenai profesi keperawatan yang diperoleh mahasiswa dari tahap akademik ini akan membentuk persepsi positif ataupun negatif dimana akan menghasilkan sikap yang hasilnya dapat terlihat ketika mahasiswa tersebut berprilaku .

\section{Metode Penelitian}

Metode yang digunakan oleh penulis adalah Literature review dengan cara menganalisis , kajian dan eksplorasi jurnal, text book, maupun e-book yang relevan dan membahas tentang hubungan antara pembelajaran konsep dasar keperawatan di perkuliahan dengan pengaplikasian proses keperawatan di rumah sakit .

Adapun jurnal yang digunakan pada literature review ini adalah jurnal yang diterbitkan dari kurun waktu 10 tahun terakhir didapatkan dengan menggunakan 2 database Portal Garuda dan Google Scholar dengan memasukkan kata kunci "Konsep Dasar Keperawatan", "Proses Keperawatan" dan, "Rumah sakit ".Artikel yang digunakan adalah sebanyak 14 referensi .

\section{Hasil Penelitian}

Berdasarkan hasil pencarian literatur didapatkan hubungan antara pembelajaran konsep dasar keperawatan di perkuliahan dengan pengaplikasian proses keperawatan di rumah sakit. Dalam literature review tersebut penelitian ini mendapatkan hasil bahwa untuk mengetahui hubungan antara pembelajaran konsep dasar keperawatan di perkuliahan dengan pengaplikasian proses keperawatan di rumah sakit dapat dilakukan dengan metode menganalisis maupun 
mengeksplorasi referensi yang telah disesuaikan dengan pengkajian.Hasilnya dapat disumpulkan bahwa ada keterkaitan antara pembelajaran mata kuliah konsep dasar keperawatan yang di pelajari oleh mahasiswa keperawatan dengan proses keperawatan yang akan mereka aplikasikan nantinya di rumah sakit.

\section{PEMBAHASAN}

Hubungan antara pembelajaran konsep dasar keperawatan di perkuliahan dengan pengaplikasian proses keperawatan di rumah sakit ternyata memiliki hubungan dimana keduanya memiliki keeretan ketika seorang mahasiswa kepreawata yang masih duduk di bangku perkuliahan mereka mempelajari banyak sekali teori dari mata kuliah konsep dasar keperawatan salah satu topik yang di pelajari dalam mata kuliah konsep dasar keprawatan (KDK) yaitu adalah proses keperawatan.Ketika seorang mahasiswa keperawatan yang sedang menempuh pendidikan di perkuliahan dan mempelajari tentang proses keperawatan tentunya apabila mahasiswa tersebut telah mempelajarinya dengan baik dan memahami prosedur proses keperawatan dengan mantap,ini membuat mahasiswa tersebut ketika sudah melakukan profesi du rumah sakit atau ketika sudah bekerja di rumah sakit akan menjadi mudah ketika dihadapkan dengan persoalan yang membutuhkan proses keperawatan untuk menyelesaikan masalah mereka tersebut.Para mahasiswa tesebut sudah mengerti bagaimana cara melakukan pengkajian,diagnosis,perencanaan,pelaksa naan ,dan evaluasi dengan baik .Maka dari itu pembelajaran Konsep dasar keperawatan di kampus sangatlah penting untuk di ikuti dan di pahami ketika mahasiswa tersebut belajar sebab di dalam pembelajaran konsep dasar keperawatan tersebut dapat ditemui cara cara menyusun proses keperatan .Hal ini lah yang membuat antara pembelajaran konsep dasar keperawatan di kelas dengan pengaplikasian proses keperawatan memiliki hubungan,karna tanpa teori yang kita pelajari di kelas kita tidak tahu bagaimana cara melakukan proses keperawatan tersebut.

\section{PEMBELAJARAN KONSEP DASAR KEPERAWATAN .}

Dalam membelajaran konsep dasar keperawatan kita mempelajari mengenai materi - materi yang berkaitan dengan keperawatan salah satu materi yang di pelajari adalah tentang proses keperawatan dimana ketika mempelajari tentang proses keperaawatan ini dapat mempermudah kita ketika bekerja di rumah sakit nantinya. 


\section{PROSES KEPERAWATAN}

Proses keperawatan adalah teknik pemecahan masalah masalah yang meliputi pengkajian ,diagnosis,perencanaan,dan evaluasi. Dimana tujuan dari proses keperawatan adalah memberikan suatu kerangka kerja berdasarkan kebutuhan klien ,keluarga dan masyarakat sehhingga membuat kebutuhan kesehatan dari pasien,keluarga,dan masyarakat dapat terpenuhi,tujuan yang lain adalah untuk memperoleh asuhan keperawatan yang berkualitas tinggi ,dan mempraktekkan metode pemecahan masalah dalam karakter keperawatan (problem solving).

Proses keperawatan memiliku fungsi yang itu sebagai kerangka berpikir untuk fungsi dan tanggung jawab keperawatan dalam ruang lingkup yang sangat luas sehingga membuat setiap tindakan yang dilakukan oleh perawat menjadi suatu hal yang profesional.dan fungsi lain dari proses keperawatan adala sebagai alat untuk mengenal masalah klien ,merencanakan secara sistematis sebab setiap tindakan yang dilakukan oleh perawat akan di catat oleh perawat tersebut.Disamping itu proses keperawatan memiliki fungsi yaitu membuat perawat terhindar dari mal praktik sehingga masyarakat atau klien akan mendapat pelayanan yang berkualitas.

\section{KESIMPULAN DAN SARAN}

Perlunya pemantapan belajar mata kuliah konsep dasar keparawatan sehingga jika seorang mahasiswa sudah menguasai teori tersebut dengan mantap akan mempermudah dirinya untuk mengaplikasikan proses keperawatan di rumah sakit,sehingga antara pembelajaran konsep dasar keperawatan di perkuliahan dengan pengaplikasian proses keperawatan di rumah sakit memiliki hubungan,penulis menyarankan agar mahasiswa keperawatan yang masih duduk di bangku perkuliahan dapat belajar dengan baik dan memantapkan konsep konsep yang telah di berikan agar ketika di hadapi di lapangan mereka dapat bekerja dengan baik dan sesuai prosedur yang akan menghasilkan pelayanan yang baik dan profesional.

\section{Daftar Pustaka}

Aini,Nur.(2018).Teori

Model

Keperawatan Beserta Aplikasinya

Dalam Keperawatan.Malang : Penebit Universitas

Muhammadiyah Malang.

Asmadi.(2008).Konsep dasar

keperawatan. Jakarta : Penerbit

Buku Kedokteran EGC.

Astari,A.,Houghty.G.S.,br

Sibuea,R.O.(2015).Sosialisasi 
Profesi dan Sikap caring pada mahasiswa di fakultas keperawatan.1(1).66-74.

Huriah,Titih.(2018). Metode Student Center Learning Aplikasi Pada Pendidikan Keperawatan.Jakarta :Penerbit Prenademia Group.

Insiyah.(2016). Implementasi Metode Self Directed Learning dan Diskusi Kelompok Kecil dalam Rangka Meningkatkan Kompetensi Menerapkan Konsep Model Keperawatan Dalam Berbagai Situasi Pada Mata Ajar Ilmu Keprawatan Dasar II.1(01).01-54.

Komarudin.(2018).Pendidikan

Keperawatan Berkelanjutan dalam Pencapain Sustaiability

Profesionalisme

Keperawatan.3(2).139-151.

Kusnanto.(2004).Pengantar Profesi dan

Praktik Keperawatan Profesional.

Jakarta : Penerbit Buku Kedokteran EGC

Lestari,S.,Widodo.,Sumardino.(2014).Pen dekatan Kultural Dalam Praktek Keperawatan Profesional di Rumah Sakit Jogja Internasional Hospital.1-8.

Marwa, A. U. (2019). Hubungan Berpikir Kritis Dalam Keperawatan Terhadap Pasien Prasekolah. INARxiv. September, 27.
Potter,P.A.,\&Perry,A.G.(2005). Buku Ajar Fundamental Keperawatan konsep , Proses dan Praktek (edisi 4).Jakarta : Penerbit Buku Kedokteran EGC

Sari,D.A.,Wijaya,D.,Purwandari,R.

(2017). Hubungan Persepsi Mahasiswa tentang Profesi Keperawatan dengan Motivasi Melanjutkan Pendidikan Profesi Ners di PSIK Universitas Jember.5(3).505-512

Saudin,D.,Kristianto,H.(2016).Rancangan Media Pembelejaran dengan Konsep Dasar Keperawatan Kegawatdaruratan.4(02).29-35.

Setyawati,A.,Koeryman,M.T.,Ermiati.(201

8).Hubungan dan Pengetahuan Sikap Mahasiswa Profesi Keperawatan Terhadap Pelaksanaan Rawat Gabung.15(02).91-96

Silaban,R.Y.,Bidjuni,H.,Hamel,R.(2016). Hubungan Motivasi Mahasiswa Sarjana Keperawatan Dengan Minat Melanjutkan studi Profesi Ners di Program studi Ilmu Keperawtan Sam Ratulangi Manado.4(01).1-5

Simamora,R.H.(2019).Menjadi Perawat yang : CIH'HUY.Surakarta : Kekata Publisher 
Susanto,R.(2010).Penerapan Standar

Proses di Puskesmas Rawat Inap

Cilacap.5(02).80-84. 